\title{
DETERMINATION OF LEAD IN CROATIAN WINES BY GRAPHITE FURNACE ATOMIC ABSORPTION SPECTROMETRY
}

\author{
Blanka TARIBA, Alica PIZENT, and Zorana KLJAKOVIĆ-GAŠPIĆ \\ Institute for Medical Research and Occupational Health, Zagreb, Croatia \\ Received in September 2010 \\ CrossChecked in October 2010 \\ Accepted in January 2011
}

\begin{abstract}
A method has been developed for direct determination of lead in wine by graphite furnace atomic absorption spectrometry (GFAAS) with Zeeman-effect background correction. The thermal behaviour of Pb during pyrolysis and atomisation stages was investigated without matrix modifier and in the presence of $\mathrm{Pd}\left(\mathrm{NO}_{3}\right)_{2}$, $\mathrm{Pd}\left(\mathrm{NO}_{3}\right)_{2}+\mathrm{Mg}\left(\mathrm{NO}_{3}\right)_{2} \times 6 \mathrm{H}_{2} \mathrm{O}$, and $\mathrm{NH}_{4} \mathrm{H}_{2} \mathrm{PO}_{4}+\mathrm{Mg}\left(\mathrm{NO}_{3}\right)_{2} \times 6 \mathrm{H}_{2} \mathrm{O}$ as matrix modifiers. A simple 1:1 dilution of wine samples with $\mathrm{Pd}\left(\mathrm{NO}_{3}\right)_{2}$ as a matrix modifier proved optimal for accurate determination of $\mathrm{Pb}$ in wine. Mean recoveries were $106 \%$ for red and $114 \%$ for white wine, and the detection limit was $3 \mu \mathrm{g} \mathrm{L}^{-1}$. Within-run precision of measurements for red and white wine was $2.1 \%$ and $1.8 \%$, respectively. The proposed method was applied for analysis of 23 Croatian wines. Median $\mathrm{Pb}$ concentrations were $33 \mu \mathrm{g} \mathrm{L}-1$, range (16 to 49) $\mu \mathrm{g} \mathrm{L}^{-1}$ in commercially available wines and $46 \mu \mathrm{g} \mathrm{L}^{-1}$, range (14 to 559) $\mu \mathrm{g} \mathrm{L}^{-1}$ in home-made wines. There were no statistically significant differences $(\mathrm{P}<0.05)$ in $\mathrm{Pb}$ concentration between commercial and home-made wines or between red and white wines.
\end{abstract}

KEY WORDS: analytical validation, commercial wines, GFAAS, home-made wines

Lead $(\mathrm{Pb})$ in wine may originate from natural and anthropogenic sources. Before the ban in the 1990s, the major source of $\mathrm{Pb}$ in wine was the atmospheric deposition of lead from leaded gasoline (1). Atmospheric contribution is now much smaller. Today instead, among the most significant sources are leadbased pesticides (2). Other factors that determine the metal concentration in wine are the capacity of grapes to take up mineral substances, type of vineyard soil, steps in the production cycle (fermentation reactions, addition of compounds with various functions), wine processing equipment, conservation, and bottling. A significant contributor to $\mathrm{Pb}$ contamination is the use of brass components in wine-making, such as pumps, valves, faucets, and piping $(3,4)$.

The maximum acceptable limit for $\mathrm{Pb}$ in wine set by the International Organization of Vine and Wine
(IOVW) is $0.15 \mathrm{mg} \mathrm{L}^{-1}$ (5). The national legislation in Croatia, however, allows the maximum level of $0.2 \mathrm{mg} \mathrm{L}^{-1}(6)$.

Lead concentration in wines deserves special consideration because of its toxicity and cumulative character. Consumption of alcoholic beverages, especially wines, can influence the concentration of $\mathrm{Pb}$ in blood (7-10). Long-term consumption of wine with high $\mathrm{Pb}$ levels could lead to chronic poisoning. Even at low levels, $\mathrm{Pb}$ is associated with hypertension, cardiovascular disease, kidney dysfunction, impaired bone synthesis, impaired sperm production and osteoporosis (11).

Because of toxicity concerns, it is important to measure $\mathrm{Pb}$ concentration in wine. Methods described so far include atomic absorption spectrometry $(3,12$, 13), inductively coupled plasma optical emission 
spectrometry (14), inductively coupled plasma mass spectrometry $(15,16)$, energy dispersive X-ray fluorescence (17), potentiometric stripping analysis, and differential pulse anodic stripping voltammetry $(13,18)$. The most common among them for determining $\mathrm{Pb}$ at trace levels is graphite furnace atomic absorption spectrometry (GFAAS) (14, 19-22), a selective, simple, and highly sensitive method, adequate for direct determination in various matrices.

This study reports a simple and fast method for direct quantitative determination of trace $\mathrm{Pb}$ in wines using GFAAS. The method was validated and applied for analysis of 23 wines obtained from six Croatian viticultural areas.

\section{MATERIALS AND METHODS}

\section{Instrumentation}

We used a Perkin-Elmer ${ }^{\circledR} 5100$ atomic absorption spectrometer (Norwalk, CO, USA) with Zeemaneffect background correction, an end-heated graphite tube atomiser (HGA-600, Perkin-Elmer Instruments, Norwalk, CO, USA), and an AS-60 furnace autosampler (Perkin-Elmer Instruments, Norwalk, CO, USA). For atomisers, we used graphite tubes with standard L'vov pyrolytic platforms. To purge the graphite tubes we used argon gas (purity $>99.999 \%$ ) with an internal flow rate of $300 \mathrm{~mL} \mathrm{~min}^{-1}$. The measurement mode was integrated absorbance. Perkin-Elmer electrodeless discharge lamp (EDL) was used to determine $\mathrm{Pb}$ at the analytical wavelength recommended by the manufacturer $(283.3 \mathrm{~nm}$, spectral bandpass $0.7 \mathrm{~nm})$. Graphite furnace heating programme used for the determination of $\mathrm{Pb}$ is shown in Table 1.

\section{Reagents and solutions}

Pyrolysis and atomisation curves were established in the absence of a chemical modifier and in the presence of $\mathrm{Pd}\left(\mathrm{NO}_{3}\right)_{2}, \mathrm{Pd}\left(\mathrm{NO}_{3}\right)_{2}+\mathrm{Mg}\left(\mathrm{NO}_{3}\right)_{2}$ × $6 \mathrm{H}_{2} \mathrm{O}$ and $\mathrm{NH}_{4} \mathrm{H}_{2} \mathrm{PO}_{4}+\mathrm{Mg}\left(\mathrm{NO}_{3}\right)_{2}$ x $6 \mathrm{H}_{2} \mathrm{O}$ as chemical modifiers. The $1 \mathrm{~g} \mathrm{~L}^{-1} \mathrm{Pd}\left(\mathrm{NO}_{3}\right)_{2}$ solution, $1 \mathrm{~g} \mathrm{~L}^{-1}$ $\mathrm{Pd}\left(\mathrm{NO}_{3}\right)_{2}+0.6 \mathrm{~g} \mathrm{~L}^{-1} \mathrm{Mg}\left(\mathrm{NO}_{3}\right)_{2} \times 6 \mathrm{H}_{2} \mathrm{O}$ and $40 \mathrm{~g} \mathrm{~L}^{-1}$ $\mathrm{NH}_{4} \mathrm{H}_{2} \mathrm{PO}_{4}+2 \mathrm{~g} \mathrm{~L}^{-1} \mathrm{Mg}\left(\mathrm{NO}_{3}\right)_{2} \times 6 \mathrm{H}_{2} \mathrm{O}$ solutions were prepared from modifier stock solutions $[(10.0 \pm 0.2) \mathrm{g}$ $\mathrm{L}^{-1} \mathrm{Pd}\left(\mathrm{NO}_{3}\right)_{2}$ in $15 \%(\mathrm{v} / \mathrm{v}) \mathrm{HNO}_{3}$, Merck, Darmstadt, Germany; $10 \% \mathrm{NH}_{4} \mathrm{H}_{2} \mathrm{PO}_{4}$, Perkin Elmer Co., Norwalk, $\mathrm{CO}, \mathrm{USA}]$ and $\mathrm{Mg}\left(\mathrm{NO}_{3}\right)_{2} \times 6 \mathrm{H}_{2} \mathrm{O}(\mathrm{BDH}$ Chemicals Ltd, Poole, England) with bi-distilled water.

Standard solutions of $\mathrm{Pb}(10,40,75,100,175$ and 250) $\mu \mathrm{g} \mathrm{L}^{-1}$ were prepared daily from a $1000 \mathrm{mg} \mathrm{L}^{-1}$ $\mathrm{Pb}$ standard solution (Merck, Darmstadt, Germany) with $12 \%(\mathrm{v} / \mathrm{v})$ ethanol (Kemika, Zagreb, Croatia) to achieve alcohol concentration similar to that of a typical wine sample. One red and one white Croatian wine were purchased at a local supermarket. Wines investigated included grape varieties Plavac mali (red) and Riesling (white). Wine samples and standard solutions were diluted (1:1) prior to analysis by mixing $500 \mu \mathrm{L}$ of wine/standard solution with $300 \mu \mathrm{L}$ of $1 \%$ $\mathrm{HNO}_{3}$ and $200 \mu \mathrm{L}$ of $0.05 \%$ Triton X-100 (BDH Chemicals Ltd, Poole, England).

\section{Wine samples}

Eight commercially available and fifteen homemade wines were obtained from six Croatian viticultural areas (Dalmatia, Hrvatsko Primorje, Istria, Prigorje, Zagorje and Slavonia) and analysed according to the developed analytical procedure. The results are presented as means of four measurements. Since the data were not normally distributed, the

Table 1 Graphite furnace heating programme for determination of lead in wine

\begin{tabular}{lcccc}
\hline Step & Temp $/{ }^{\circ} \mathbf{C}$ & Ramp $/ \mathbf{s}$ & Hold $/ \mathbf{s}$ & Internal flow $/ \mathbf{~ m L ~} \mathbf{~ m i n}^{-1}$ \\
\hline Drying & 110 & 1 & 30 & 300 \\
\hline Drying & 140 & 10 & 25 & 300 \\
\hline Pyrolysis & 1100 & 1 & 30 & 300 \\
\hline Cooling-down & 20 & 1 & 15 & 300 \\
\hline Atomisation & 2000 & 0 & 5 & 0 \\
\hline Cleaning & 2600 & 1 & 5 & 300 \\
\hline
\end{tabular}


significance of the difference in $\mathrm{Pb}$ concentrations between the groups of commercial and home-made wines and white and red wines was calculated by using the Mann-Whitney U-test. Results were considered to be significant at the $5 \%$ critical level $(\mathrm{P}<0.05)$.

\section{RESULTS AND DISCUSSION}

\section{Optimisation}

Compared to aqueous solutions, wine is a fairly complex matrix due to its organic content, especially ethanol, which influences sample transport to atomisation devices because of changes in density and surface tension (23). Matrix-matched calibration makes it possible to prepare standard solutions as similar as possible to samples $(14,20,24-26)$.

Optimisation of the furnace programme was based on the pyrolysis and atomisation curves (Figure 1) for a standard solution of $\mathrm{Pb}\left(20 \mu \mathrm{g} \mathrm{L}^{-1}\right)$ containing $12 \%$ ethanol in order to simulate wine matrix, and diluted samples (1:1) of one red and one white wine. The effect of pyrolysis and atomisation temperature on sample absorbance was tested in the absence and in the presence of three modifiers. The results indicate a similar thermal behaviour of $\mathrm{Pb}$ in the standard solution and in wine samples. Modifiers showed a stabilising effect on $\mathrm{Pb}$ in the standard solution as well as in wine samples. $\mathrm{Pd}$ modifier and $\mathrm{Mg} / \mathrm{Pd}$ modifier ensured stability of $\mathrm{Pb}$ to up to $1200{ }^{\circ} \mathrm{C}$, while phosphate/Mg modifier was associated with a loss in sensitivity over $900{ }^{\circ} \mathrm{C}$. In addition, matrix modifiers enhanced the integrated absorbance signal in red wine analysis, for which the optimal pyrolysis temperature was $1100{ }^{\circ} \mathrm{C}$ and optimal modifiers $\mathrm{Pd}$ and $\mathrm{Mg} / \mathrm{Pd}$. During optimisation of atomisation temperature, we observed a slightly better sensitivity with the Pd than with the $\mathrm{Mg} / \mathrm{Pd}$ modifier at pyrolysis temperature of $1100{ }^{\circ} \mathrm{C}$. Maximum sensitivity was obtained when atomisation temperature was $2000^{\circ} \mathrm{C}$. Based on these results, we selected $1 \mathrm{~g} \mathrm{~L}^{-1} \mathrm{Pd}$ as the optimum modifier for determination of $\mathrm{Pb}$ in wines, with the pyrolysis temperature of $1100^{\circ} \mathrm{C}$ and the atomisation temperature of $2000{ }^{\circ} \mathrm{C}$.

\section{Method validation}

The linear calibration was obtained using six standard solutions prepared in $12 \%(\mathrm{v} / \mathrm{v})$ ethanol in the range of $10 \mu \mathrm{g} \mathrm{L}^{-1}$ to $250 \mu \mathrm{g} \mathrm{L}^{-1} \mathrm{~Pb}$. Relative standard deviations of five replicate samples for each
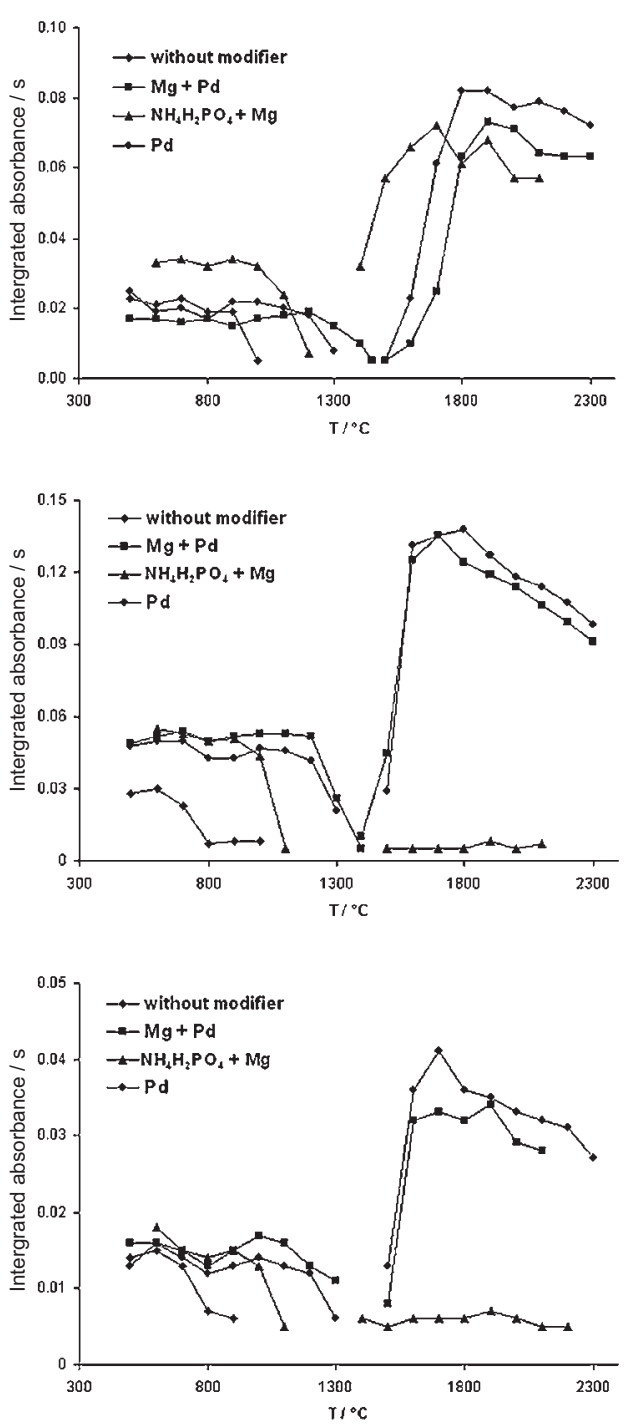

Figure 1 Pyrolysis and atomisation curves in the absence and in the presence of different modifiers for: a) standard solution $\left(20 \mu \mathrm{g} \mathrm{L}^{-1}\right)$; b) red wine sample (dilution 1:1); c) white wine sample (dilution 1:1)

standard solution were lower than $3 \%$. The correlation coefficient $(\mathrm{R})$, obtained by linear fitting to the calibration points, was better than 0.9995 . Accuracy was evaluated by standard additions to determine recovery of the spiked analyte. Spike recovery tests were carried out with one red and one white commercially available Croatian wine, because no certified reference material was available. Wine samples were spiked with five concentration levels of $\mathrm{Pb}$, and added spike concentration did not exceed $30 \mu \mathrm{g} \mathrm{L}^{-1}$ for the red wine sample (Merlot), and $40 \mu \mathrm{g} \mathrm{L}^{-1}$ for the white wine sample (Riesling). Adding an appropriate volume of standard solution of $\mathrm{Pb}$ to commercially available Croatian wines resulted in an 
Table 2 Lead concentrations in analysed wines

\begin{tabular}{|c|c|c|c|c|}
\hline Area & Grape variety & Wine type & Vintage & $\gamma(\mathbf{P b})^{\mathrm{a}} / \mu \mathrm{g} \mathrm{\textrm {L } ^ { - 1 }}$ \\
\hline \multicolumn{5}{|l|}{ Commercial } \\
\hline Ston & Plavac mali & Dry red & 2007 & $48 \pm 2$ \\
\hline Pelješac & Plavac mali & Semi-dry red & 2008 & $16 \pm 2$ \\
\hline Istria & Merlot & Dry red & 2008 & $29 \pm 2$ \\
\hline Istria & Malvasia & Dry white & 2008 & $49 \pm 1$ \\
\hline Istria & Malvasia & Dry white & 2009 & $40 \pm 1$ \\
\hline Đakovo & Riesling & Dry white & 2007 & $22 \pm 1$ \\
\hline Kutjevo & Riesling & Dry white & 2008 & $21 \pm 2$ \\
\hline \multirow[t]{2}{*}{ Srijem } & Chardonnay & Dry white & 2007 & $36 \pm 1$ \\
\hline & & & & $33(16 \text { to } 49)^{b}$ \\
\hline \multicolumn{5}{|l|}{ Home made } \\
\hline Kaštel Kambelovac & Plavac mali & Dry red & 2009 & $43 \pm 1$ \\
\hline Kaštel Lukšić & Crljenak & Dry red & 2009 & $46 \pm 2$ \\
\hline Kaštel Lukšić & Babić & Dry red & 2009 & $58 \pm 1$ \\
\hline Vrgorac & Vranac & Dry red & 2009 & $68 \pm 2$ \\
\hline Istria & Merlot + Vranac & Dry red & 2009 & $259 \pm 3$ \\
\hline Istria & Merlot & Dry red & 2009 & $82 \pm 1$ \\
\hline $\mathrm{Rab}$ & Plavac mali & Dry red & 2009 & $559 \pm 3$ \\
\hline Istria & Refosco & Dry red & 2009 & $31 \pm 2$ \\
\hline Istria & Mix & Dry red & 2009 & $36 \pm 2$ \\
\hline Istria & Malvasia & Dry white & 2009 & $51 \pm 1$ \\
\hline $\mathrm{Rab}$ & Mix & Dry white & 2009 & $276 \pm 2$ \\
\hline Kalnik & Semillon & Dry white & 2009 & $14 \pm 2$ \\
\hline Trema & Riesling + Silvaner & Dry white & 2009 & $17 \pm 1$ \\
\hline Donje Križevčine & Riesling + Kraljevina & Dry white & 2009 & $16 \pm 1$ \\
\hline \multirow[t]{2}{*}{ Varaždin } & Mix & Dry white & 2009 & $19 \pm 0.5$ \\
\hline & & & & $46(14 \text { to } 559)^{\mathrm{b}}$ \\
\hline
\end{tabular}

${ }^{a}$ Mean \pm standard deviation

${ }^{b}$ Median value and range

average recovery of $106 \%$ for red, and $114 \%$ for white wine. The sensitivity of the calibration curves for the spiked samples (sensitivity white wine $=0.0042$; sensitivity $_{\text {red wine }}=0.0038$ ) was similar to the sensitivity of the calibration curve for the matrix-matched standard solutions, indicating that there were no matrix effects and the selectivity of the method was satisfactory. The characteristic masses of the standard solutions $\left(\mathrm{m}_{0}=11 \mathrm{pg}\right)$ were within the $6 \%$ of the recommended value for $\mathrm{Pb}\left(\mathrm{m}_{\text {recomended }}=12 \mathrm{pg}\right.$ ) (27). Measurements of ten different replicates of one red and one white wine sample (measured in triplicates) gave relative standard deviations of $2.1 \%$ and $1.8 \%$, respectively, indicating high within-run precision.

The detection limit $\left(3 \mu \mathrm{g} \mathrm{L}^{-1}\right)$ was calculated as three times the standard deviation of 25 consecutive measurements of blank $(3 \sigma)$. The quantification limit $\left(9 \mu \mathrm{g} \mathrm{L}^{-1}\right)$ was calculated as ten times the standard deviation of 25 consecutive measurements of the blank $(10 \sigma)$.

\section{Analysis of wine samples}

Eight commercially available and fifteen homemade wines were analysed according to the developed analytical procedure (Table 2). The median $\mathrm{Pb}$ concentration in commercially available Croatian wines was $33 \mu \mathrm{g} \mathrm{L}^{-1}$ (range from $16 \mu \mathrm{g} \mathrm{L}^{-1}$ to $49 \mu \mathrm{g}$ $\mathrm{L}^{-1}$ ), which is far below the upper permissible limits $(5,6)$. In home-made wines $\mathrm{Pb}$ concentration ranged from $14 \mu \mathrm{g} \mathrm{L}^{-1}$ to $559 \mu \mathrm{g} \mathrm{L}^{-1}$, and the median was $46 \mu \mathrm{g} \mathrm{L}^{-1}$. Concentration above the permitted level established in Croatia of $200 \mu \mathrm{g} \mathrm{L}{ }^{-1}$ was found in three 
home-made wines. Regardless the wider range of concentrations in home-made wines, we found no significant differences $(\mathrm{P}<0.05)$ in $\mathrm{Pb}$ concentrations between commercial and home-made wines or between red and white wines.

Although wine is relatively widely consumed drink in Croatia (28), there are limited data on $\mathrm{Pb}$ concentrations in Croatian wines. Our results are generally in agreement with the results obtained by Banović et al. (12), where $\mathrm{Pb}$ concentration ranged from $67 \mu \mathrm{g} \mathrm{L}^{-1}$ to $355 \mu \mathrm{g} \mathrm{L}^{-1}$ (median $190 \mu \mathrm{g} \mathrm{L}^{-1}$ ). Vinković-Vrček et al. (16) found lower concentrations of $\mathrm{Pb}$ in conventionally and organically produced red and white Croatian wines; mean concentrations ranged from $1.15 \mu \mathrm{g} \mathrm{L}^{-1}$ to $7.23 \mu \mathrm{g} \mathrm{L}^{-1}$. In contrast, $\mathrm{Pb}$ in Croatian wines investigated by Šeruga et al. (13) ranged from $4.39 \mu \mathrm{g} \mathrm{L}^{-1}$ to $35.52 \mu \mathrm{g} \mathrm{L}^{-1}$ (mean $\left.9.50 \mu \mathrm{g} \mathrm{L}^{-1}\right)$. Considering the findings from other parts of Europe, our results are similar to those obtained for 45 Cretan wines by Galani-Nikolakaki et al. (24), where $\mathrm{Pb}$ ranged from $18 \mu \mathrm{g} \mathrm{L}^{-1}$ to $421 \mu \mathrm{g} \mathrm{L} \mathrm{L}^{-1}$ (median $64 \mu \mathrm{g} \mathrm{L}^{-1}$ ). Somewhat similar concentrations of $\mathrm{Pb}$ were found in wines from Serbia $(29,30)$ and Germany (31). Especially high values of $\mathrm{Pb}$, up to $1125 \mu \mathrm{g} \mathrm{L}^{-1}$, were found in wines widely consumed in Spain (32), but also in wine samples from a Czech viticulture region (from 10.9 to $1253 \mu \mathrm{g} \mathrm{L}^{-1}$; mean $67.1 \mu \mathrm{g} \mathrm{L}^{-1}$ ) (33). Lower $\mathrm{Pb}$ concentrations than in our study were found in Brazilian (21), Uruguayan (3), and Portuguese wines (34).

\section{CONCLUSION}

In the GFAAS method we developed to determine $\mathrm{Pb}$ in wine no sample preparation was required, save for the dilution step. This enables direct determination with little chance of contamination. Our results and recovery values of spiked samples indicate that a simple 1:1 dilution of the samples was sufficient to accurately determine $\mathrm{Pb}$ in Croatian wines. Although obviously not enough samples were investigated in this work to allow general conclusions, our findings appear to be in agreement with values reported by other investigators.

Even though $13 \%$ of the wine samples tested exceeded the maximum permissible limit established by the International Organization of Vine and Wine and by Croatian law, consumption of such wines does not pose any imminent toxicological risk to moderate wine consumers (i.e. if they consume one or two glasses of wine per day).

\section{REFERENCES}

1. Médina B, Augagneur S, Barbaste M, Grousset FE, BuatMénard P. Influence of atmosferic pollution on the lead content of wines. Food Addit Contam 2000;17:435-45.

2. Handson PD. Lead and arsenic levels in wines produced from vineyards where lead arsenate sprays are used for caterpillar control. J Sci Food Agric 1984;35:215-8.

3. Rivero Huguet ME. Monitoring of $\mathrm{Cd}, \mathrm{Cr}, \mathrm{Cu}, \mathrm{Fe}, \mathrm{Mn}, \mathrm{Pb}$ and $\mathrm{Zn}$ in fine Uruguayan wines by atomic absorption spectroscopy. At Spectrosc 2004;25:177-84.

4. Kaufmann A. Lead in wine. Food Addit Contam 1998;15: 437-45.

5. International Organisation of Vine and Wine (IOVW). 2006. International code of oenological practices 2006 [displayed 16 July 2010]. Available at: http://news.reseau-concept.net/ images/oiv_uk/Client/PNO02A_CODE\%20Ed\%202006\% 20EN.pdf.

6. Pravilnik o toksinima, metalima, metaloidima te drugim štetnim tvarima koje se mogu nalaziti u hrani [Legislation on toxins, metals, metaloids and other harmful supstances that could be contained in food, in Croatian]. Narodne novine $16 / 2005$.

7. Elinder CG, Lind B, Nilsson B. Wine - an important source of lead exposure. Food Addit Contam 1988;5:641-4.

8. Schuhmacher M, Domingo JL, Llobet JM, Corbella J. Variability of blood lead levels in an urban population in relation to drinking and smoking habits. Sci Total Environ 1993;138:23-9.

9. Dally S, Girre C, Hispard E, Thomas G, Fournier L. High blood lead level in alcoholics: wine vs. beer. Drug Alcohol Depen 1989;23:45-8.

10. Lopez CM, Vallejo NE, Piňeiro AE, Uicich R, Damin CF, Sarchi MI, Villaamil Lepori EC, Roses OE. Alteration of biochemical parameters related with exposure to lead in heavy alcohol drinkers. Pharmacol Res 2002;45:47-50.

11. World Health Organization (WHO). Lead. Environmental Health Criteria 3, 1977 [displayed 16 July 2010]. Available at http://www.inchem.org/documents/ehc/ehc/ehc003.htm.

12. Banović M, Kirin J, Ćurko N, Kovačević Ganić K. Influence of vintage on $\mathrm{Cu}, \mathrm{Fe}, \mathrm{Zn}$ and $\mathrm{Pb}$ content in some Croatian red wines. Czech J Food Sci 2009;29:401-3.

13. Šeruga M, Nemet I, Laslavić B. Heavy metals content of some Croatian wines. Deut Lebensm Rundsch 2008;104: 46-55.

14. Lara R, Cerutti S, Salonia JA, Olsina RA, Martinez LD. Trace element determination of Argentine wines using ETAAS and USN-ICP-OES. Food Chem Toxicol 2005;43:293-7.

15. Castiňeira MM, Brandt R, van Bohlen A, Jakubowski N. Development of a procedure for the multielement determination of trace elements in wine by ICP-MS. Fresenius J Anal Chem 2001;370:553-8.

16. Vinković Vrček I, Bojić M, Žuntar I, Mendaš G, Medić-Šarić M. Phenol content, antioxidant activity and metal composition of Croatian wines deriving from organically and conventionally grown grapes. Food Chem 2011;124:354-61. 
17. Oreščanin V, Katunar A, Kutle A, Valković V. Heavy metals in soil, grape, and wine. J Trace Microprobe Techn 2003;21:171-80.

18. Oehme M, Lund W. Determination of cadmium, lead and copper in wine by differential pulse anodic stripping voltammetry. Fresenius Z Anal Chem 1979;294:391-7.

19. Ajtony Z, Szoboszlai N, Suskó EK, Mezei P, György K, Bencs L. Direct sample introduction of wines in graphite furnace atomic absorption spectrometry for the simultaneous determination of arsenic, cadmium, copper and lead content. Talanta 2008;76:627-34.

20. Dessuy MB, Vale MGR, Souza AS, Ferreira SLC, Welz B, Katskov DA. Method development for the determination of lead in wine using electrothermal atomic absorption spectrometry comparing platform and filter furnace atomizers and different chemical modifiers. Talanta 2008;74:1321-9.

21. Freschi GPG, Dakuzaku CS, de Moraes M, Nóbrega JA, Gomes Neto JA. Simultaneous determination of cadmium and lead in wine by electrothermal atomic absorption spectrometry. Spectrochim Acta Part B 2001;56:1987-93.

22. Kim M. Determination of lead and cadmium in wines by graphite furnace atomic absorption spectrometry. Food Addit Contam 2004;21:154-7.

23. Aceto M, Abollino O, Bruzzoniti MC, Mentasti E, Sarzanini C, Malandrino M. Determination of metals in wine with atomic spectroscopy (flame-AAS, GF-AAS and ICP-AES): a review. Food Add Contam 2002;19:126-33.

24. Galani-Nikolakaki S, Kallithrakas-Kontos N, Katsanos AA. Trace element analysis of Cretan wines and wine products. Sci Total Environ 2002;285:155-63.

25. Mirlean M, Roisenberg A, Chies JO. Copper-based fungicide contamination and metal distribution in Brazilian grape products. Bull Environ Contam Toxicol 2005;75:968-74.
26. Tripković M, Todorović M, Holclajtner-Antunović I, Ražić S, Kandić A, Marković D. Spectrochemical determination of lead in wines. J Serb Chem Soc 2000;65:323-29.

27. Slavin W. Graphite furnace AAS for biological materials. Sci Total Environ 1988;71:17-35.

28. Milošević M, Mustajbegović J, Abdović S, Sulentić P, Pucarin-Cvetković J. Usporedba regionalne potrošnje alkoholnih pića i kardiovaskularnih čimbenika rizika u Hrvatskoj [Relationship of regional alcohol drinking habit and cardiovascular risk factors in Croatia, in Croatian]. Acta Med Croat 2007;61:275-9.

29. Ražić $\mathrm{S}$, Čokeša $Đ$, Sremac S. Multivariate data visualization methods based on elemental analysis of wines by atomic absorption spectrometry. J Serb Chem Soc 2007;72:148792.

30. Suturović ZJ, Marjanović NJ. Determination of zinc, cadmium, lead and copper in wines by potentiometric stripping analysis. Nahrung/Food 1998;42:36-8.

31. Ostapczuk P, Eschnauer HR, Scollary GR. Determination of cadmium, lead and copper in wine by potentiometric stripping analysis. Fresenius J Anal Chem 1997;358:723-7.

32. Mena CM, Cabrera C, Lorenzo ML, Lopez MC. Determination of lead contamination in Spanish wines and other alcoholic beverages by flow injection atomic absorption spectrometry. J Agric Food Chem 1997;45:1812-5.

33. Kment P, Mihaljevič M, Ettler V, Šebek O, Strnad L, Rohlová L. Differentiation of Czech wines using multielement composition - A comparison with vineyard soil. Food Chem 2005;91:157-65.

34. Azenha MAGO, Vasconcelos MTSD. Assessment of the Pb and $\mathrm{Cu}$ in vitro availability in wines by means of speciation procedures. Food Chem Toxicol 2000;38:899-912. 


\title{
Sažetak
}

\section{ODREĐIVANJE OLOVA U HRVATSKIM VINIMA ELEKTROTERMIČKOM ATOMSKOM APSORPCIJSKOM SPEKTROMETRIJOM}

\begin{abstract}
Razvijena je metoda za izravno određivanje olova u vinu primjenom elektrotermičke atomske apsorpcijske spektrometrije (ETAAS) uz Zeemanovu korekciju nespecifične apsorpcije. Termalno ponašanje $\mathrm{Pb}$ za vrijeme pirolize $\mathrm{i}$ atomizacije uzorka ispitano je bez primjene modifikatora matrice te $\mathrm{u}$ prisutnosti modifikatora $\mathrm{Pd}\left(\mathrm{NO}_{3}\right)_{2}, \mathrm{Pd}\left(\mathrm{NO}_{3}\right)_{2}+\mathrm{Mg}\left(\mathrm{NO}_{3}\right)_{2}$ × $6 \mathrm{H}_{2} \mathrm{O}$ i $\mathrm{NH}_{4} \mathrm{H}_{2} \mathrm{PO}_{4}+\mathrm{Mg}\left(\mathrm{NO}_{3}\right)_{2}$ x $6 \mathrm{H}_{2} \mathrm{O}$. Pokazalo se kako je jednostavno razrjeđenje uzoraka (1:1), uz $\mathrm{Pd}\left(\mathrm{NO}_{3}\right)_{2}$ kao modifikator, optimalno za točno određivanje $\mathrm{Pb}$ u vinima. Srednje vrijednosti analitičkih povrata bile su $106 \%$ za crno i $114 \%$ za bijelo vino, dok je granica detekcije mjerenja iznosila $3 \mu \mathrm{g} \mathrm{L}^{-1}$. Preciznost mjerenja unutar istog dana iznosila je 2,1 \% za crno vino te $1,8 \%$ za bijelo vino. Metoda je primijenjena za analizu 23 -ju uzoraka vina hrvatskog podrijetla. Koncentracije $\mathrm{Pb}$ bile su u rasponu od $16 \mu \mathrm{g} \mathrm{L}^{-1}$ do $49 \mu \mathrm{g} \mathrm{L}^{-1}$ (medijan $33 \mu \mathrm{g} \mathrm{L}^{-1}$ ) u komercijalnim vinima te od $14 \mu \mathrm{g} \mathrm{L}^{-1}$ do $559 \mu \mathrm{g} \mathrm{L}^{-1}$ (medijan $46 \mu \mathrm{g} \mathrm{L}^{-1}$ ) u vinima domaće proizvodnje. Nije pronađena statistički značajna razlika između koncentracije $\mathrm{Pb}$ u komercijalnim i domaćim vinima, kao ni razlika između crnih i bijelih vina.
\end{abstract}

KLJUČNE RIJEČI: analitičko vrednovanje, domaća vina, ETAAS, komercijalna vina

\section{CORRESPONDING AUTHOR:}

Blanka Tariba

Analytical Toxicology and Mineral Metabolism Unit Institute for Medical Research and Occupational Health P.O. Box 291, HR-10001 Zagreb, Croatia

E-mail: btariba@imi.hr 